\title{
Genistein and other soya isoflavones are potent ligands for transthyretin in serum and cerebrospinal fluid
}

\author{
Branislav Radović*, Birgit Mentrup and Josef Köhrle \\ Institut für Experimentelle Endokrinologie und Endokrinologisches Forschungszentrum (EnForCé), Charité Universitätsmedizin \\ Berlin, Schumannstrasse 20-21, 10117, Berlin, Germany
}

(Received 15 July 2005 - Revised 24 January 2006 - Accepted 10 February 2006)

\begin{abstract}
Consumption of soya-based nutrients is increasing in modern society because of their potentially protective effects against chronic diseases. Soya products are also heavily advertised as alternative drugs for relief from symptoms of the menopause and for hormone replacement therapy. However, because of their oestrogenic activity, negative effects of isoflavones have been postulated. Therefore, we analysed influences of soya isoflavones, major soya constituents with endocrine activity, on thyroxine $\left(T_{4}\right)$ binding to its distribution proteins. Serum binding of ${ }^{125} \mathrm{I}-\mathrm{labelled} \mathrm{L}-\mathrm{T}_{4}$ was analysed in the absence or presence of increasing concentrations of soya isoflavones using non-denaturing PAGE for analysis. Complete displacement of $\left[{ }^{125} \mathrm{I}\right] \mathrm{T}_{4}$ binding to transthyretin (TTR) was observed in human serum incubated with genistein at concentrations $>10 \mu \mathrm{M}$; interference started at $>0 \cdot 1 \mu \mathrm{M}$. Glycitein showed decreased and daidzein the lowest displacement potency. $\left[{ }^{125} \mathrm{I}^{\mathrm{T}} \mathrm{T}_{4}\right.$ was displaced to albumin in rat and to $\mathrm{T}_{4}$-binding globulin in human serum. Soya isoflavones also obstruct $\left[{ }^{125} \mathrm{I}\right] \mathrm{T}_{4}$ binding to TTR in human cerebrospinal fluid (CSF). The inhibitory effect was confirmed in direct binding assays using purified TTR with $50 \%$ inhibitory concentration values of $0.07 \mu \mathrm{M}$ for genistein, $0.2 \mu \mathrm{M}$ for glycitein and $1.8 \mu \mathrm{M}$ for daidzein. The present study underlined a potent competition of soya isoflavones for $\mathrm{T}_{4}$ binding to TTR in serum and CSF. Isoflavones might alter free thyroid hormone concentrations resulting in altered tissue availability and metabolism. As a consequence of this interference, one could expect a disturbance in the feedback regulation of hormonal networks, including the pituitary-thyroid-periphery axis during development and in adult organisms.
\end{abstract}

Thyroxine: Transthyretin: Genistein: Isoflavones: Cerebrospinal fluid

Several experimental and clinical studies have shown that consumption of soya and soya food products have beneficial effects on human health. Particularly, studies on soya isoflavones revealed their possible protective role against different forms of cancer, osteoporosis, CVD and renal disease (Tham et al. 1998; Messina, 1999; Anderson et al. 1999; Lissin \& Cooke, 2000; Jin \& MacDonald, 2002; Cross et al. 2004; Duncan et al. 2005). Their structural similarities to $17 \beta$-oestradiol, and ability to preferentially bind to oestrogen receptor $\beta\left(50 \%\right.$ inhibitory concentration $\left(\mathrm{IC}_{50}\right)$ values of $8.4 \mathrm{~nm}$ for genistein and $100 \mathrm{~nm}$ for daidzein) and sex hormone-binding globulin (Kuiper et al. 1998; Dixon \& Ferreira, 2002; Doerge \& Sheehan, 2002), identified these soya isoflavones as acting as potential selective oestrogen receptor modulators, this being the reason for their wide but controversial use in relieving postmenopausal symptoms in women.

Despite the numerous beneficial effects of soya isoflavones, epidemiological and experimental data also exist showing an adverse effect on human health. Soya isoflavones exhibit oestrogen activity but, administered during development, can cause adverse oestrogen effects in experimental animals (Dixon \& Ferreira, 2002). The main isoflavone genistein also inhibits tyrosine kinase $\left(\mathrm{IC}_{50}\right.$ about $\left.150 \mu \mathrm{M}\right)$ and other protein kinases by acting as a competitive inhibitor of ATP binding at higher doses than needed for oestrogen receptor binding (Akiyama et al. 1987). Recently it was found that mice neonatally exposed to genistein develop uterine cancer later in their life, reminiscent of certain effects of oestrogen analogues, such as diethylstilbestrol (Newbold et al. 2001). The negative effects of soya on the pituitary-thyroid axis are also well described in human subjects and animals. The studies on rats revealed associations between goitrogenesis and soya consumption, and the protective effect of adequate dietary iodide intake (Block et al. 1961; Nordsiek, 1962; Konijn et al. 1972; Kay et al. 1988). Hypothyroidism and goitre were also observed in infants consuming soya formula (van Wyk et al. 1959; Hydovitz, 1960; Shepard et al. 1960; Ripp, 1961; Pinchera et al. 1965; Labib et al. 1989; Chorazy et al. 1995; Jabbar et al. 1997); however, goitre was reversed after switching to cows' milk or iodine supplementation.

There are at least three different levels at which soya isoflavones can interact with the thyroid hormone system: at the thyroid gland; in metabolism (with feedback mechanisms); with thyroid hormone transport proteins (Köhrle, 2000). Genistein and daidzein were identified as potent inhibitors of thyroid peroxidase, a key enzyme in thyroid hormone synthesis, in vitro and in vivo (Divi et al. 1997; Chang \& Doerge, 2000; Doerge \& Sheehan, 2002). They block both 
iodination of tyrosine residues on thyroglobulin and the coupling of two iodinated tyrosine molecules to yield iodothyronines. Daidzein and genistein also affect the metabolism of thyroid hormones and iodide re-utilisation in the human thyroid by inhibition of sulfotransferase enzymes (Ebmeier \& Anderson, 2004).

In the healthy adult rat, thyroid hormones are transported to target tissues primarily bound to transthyretin (TTR), the major serum distributor protein for thyroid hormone in rodents (Young et al. 1982). This is in contrast to human serum, where thyroxine-binding globulin (TBG) binds thyroxine $\left(\mathrm{T}_{4}\right)$ with highest affinity. Flavonoids are strongly and preferentially bound to TTR in most species, including man, but show no or only minor competition with thyroid hormone for binding to TBG, or to serum albumin (Köhrle et al. 1989). In the present in vitro study, we report the influence of soya isoflavones (Fig. 1) on thyroid hormone binding and distribution, in particular on the binding of $\mathrm{T}_{4}$ to its distributor proteins in human and rat serum as well as in human cerebrospinal fluid (CSF).

\section{Materials and methods}

\section{Chemicals and materials}

${ }^{125}$ I-labelled $\mathrm{L}_{-} \mathrm{T}_{4}$ (specific activity $4 \cdot 99-6 \cdot 10 \mathrm{MBq} / \mu \mathrm{g}$ ) was purchased from Perkin Elmer (Billerica, MA, USA). 3,3',5,5'-Tetraiodo-L- $\mathrm{T}_{4}$ was kindly provided from Henning Berlin (Germany). Human purified TTR and TBG were prepared by Vivian Cody (Hauptman-Woodward Medical Research Institute, Buffalo, NY, USA). The soya isoflavone genistein was purchased from Sigma-Aldrich (Germany) and isoflavones daidzein and glycitein were kindly provided by Sabine Kulling (Karlsruhe, Germany). The Wistar rat serum pool was kindly provided by Franziska Götz (Institute of Experimental Endocrinology, Charité, Berlin, Germany) and the human serum pool and CSF pool from Lutz Schomburg and Ulrich Schweizer (Institute of Experimental Endocrinology, Charité, Berlin, Germany), respectively.

\section{Analysis of thyroxine binding to serum proteins}

Binding of ${ }^{125}$ I-labelled $\mathrm{T}_{4}$ to serum and CSF proteins was assessed by non-denaturing PAGE, as previously described
(Young et al. 1982). The sera and CSF samples $(10 \mu 1)$ were incubated in $1.5 \mathrm{ml}$ Eppendorf tubes for $30 \mathrm{~min}$ at room temperature with $10 \mu \mathrm{l}\left[{ }^{125} \mathrm{I}_{\mathrm{T}}\right.$ (about $740 \mathrm{~Bq}$ ) diluted in 0.02 M-phosphate buffer ( $\mathrm{pH} 9$ ) in the absence or presence of increasing concentrations of soya isoflavones $(0 \cdot 1-100 \mu \mathrm{mol} / \mathrm{l})$. Samples $(60 \mu \mathrm{l})$ of the incubated mixture were loaded on nondenaturing PAGE gels and run for $14 \mathrm{~h}$ at $50 \mathrm{~V}$ in a tri(hydroxymethyl)-aminomethane-glycine native running buffer ( $\mathrm{pH} 8.4$ ). The temperature was maintained at $6^{\circ} \mathrm{C}$ by the Bio-Rad Protean II xi cooling electrophoresis chamber (Bio-Rad Laboratories, Hercules, CA, USA). Gels were sealed in a plastic transparent bag and exposed to phosphoimager plates overnight, before scanning. The distribution of radiolabelled $\mathrm{T}_{4}$ to individual binding proteins was analysed and quantified by a Cyclone storage phosphor screen (Packard Instrument Company Inc., Meriden, CT, USA).

\section{In vitro thyroxine-transthyretin competition-binding studies}

The analysis of the capacity of soya isoflavones to compete with $\mathrm{T}_{4}$ binding to purified human TTR was performed as described previously (Somack et al. 1982), with slight modifications (Auf'mkolk et al. 1986). The assay mixture was a $0 \cdot 1 \mathrm{M}$-tri(hydroxymethyl)-aminomethane- $\mathrm{HCl}$ buffer ( $\mathrm{pH}$ 8.0) containing $0 \cdot 1 \mathrm{M}-\mathrm{NaCl}$ and $1 \mathrm{~mm}$-EDTA, purified human TTR $(2.5 \mu \mathrm{g} /$ $\mu \mathrm{l}=23 \mathrm{nmol} / \mathrm{l}), \quad{ }^{125}$ I-labelled $\quad \mathrm{L}_{-} \mathrm{T}_{4} \quad(610 \mathrm{~Bq} /$ tube, about $50000 \mathrm{cpm}$ ) and competitors (soya isoflavones) with increasing concentrations $(0 \cdot 001-10 \mu \mathrm{mol} / \mathrm{l})$, in a total volume of $100 \mu \mathrm{l}$. Control incubations contained $1 \%$ dimethylsulfoxide, which was the solvent, instead of the competitor. The incubation mixtures were allowed to reach binding equilibrium at room temperature for $30 \mathrm{~min}$, and incubation was stopped by adding $0.5 \mathrm{ml}$ ice-cold dextran-coated charcoal. TTR-bound and free $\left[{ }^{125} \mathrm{I}\right] \mathrm{T}_{4}$ were separated after $10 \mathrm{~min}$ of incubation at $4^{\circ} \mathrm{C}$ by $10 \mathrm{~min}$ centrifugation at $3000 \mathrm{~g}$. The decanted supernatant fraction was counted in an LKB Wallac $1277 \gamma$ counter (Wallac, Milton Keynes, Bucks, UK). Unspecific binding, determined by adding $\mathrm{L}^{-\mathrm{T}_{4}}(10 \mu \mathrm{mol} / \mathrm{l})$, was subtracted to obtain specific binding data. All analyses were performed with data from at least three different experiments performed in duplicate. Calculation of binding parameters was performed with GraphPad Prism version 4 for Windows (GraphPad Software Inc., San Diego, CA, USA).<smiles>NC(Cc1cc(I)c(Oc2cc(I)c(O)c(I)c2)c(I)c1)C(=O)O</smiles>

(B)<smiles>O=c1c(-c2ccc(O)cc2)coc2cc(O)cc(O)c12</smiles><smiles>COc1cc2c(=O)c(-c3ccc(O)cc3)coc2cc1O</smiles><smiles>O=c1c(-c2ccc(O)cc2)coc2cc(O)ccc12</smiles>

Fig. 1. Structural formulas of thyroxine (A) and soya isoflavones used in the study: genistein (B); glycitein (C); daidzein (D). 


\section{Results}

Increasing concentrations of soya isoflavones added to human and rat serum and human CSF progressively inhibited the binding of ${ }^{125}$ I-labelled $\mathrm{L}_{-} \mathrm{T}_{4}$ to TTR. Native PAGE images presented in Fig. 2 show a representative example of the most potent competitor, genistein. Complete inhibition of $\left[{ }^{125} \mathrm{I}\right] \mathrm{T}_{4}$ binding to TTR was achieved at a concentration of $>10 \mu \mathrm{mol}$ genistein/l in human serum with interference starting at $>0 \cdot 1 \mu \mathrm{M}$ concentrations (Fig. 2 (A)). The labelled hormone was displaced from TTR to TBG and albumin. The displacement potency decreased with the decrease in concentration of the competitor.

Fig. 2 (B) shows the effect of genistein on $\left[{ }^{125} \mathrm{I}_{\mathrm{T}} \mathrm{T}_{4}\right.$ binding to TTR in human CSF, which contains no TBG or albumin. Complete and marked displacement was observed at concentrations of 100 and $10 \mu \mathrm{mol} / \mathrm{l}$ respectively, leading to an increased amount of free $\left[{ }^{125} \mathrm{I}_{\mathrm{T}}\right.$ (lanes 5 and 6 ). Genistein added to pooled rat serum markedly inhibited the $\left[{ }^{125} \mathrm{I}\right] \mathrm{T}_{4}$ binding to TTR at the concentrations of 100 and $10 \mu \mathrm{mol} / \mathrm{l}$ (Fig. 2 (C)). The labelled hormone was displaced from TTR to albumin. The other soya isoflavones, glycitein and daidzein, influence the $\left[{ }^{125} \mathrm{I}_{\mathrm{T}} \mathrm{T}_{4}\right.$ binding to serum and CSF proteins in the same manner, but with lower potency (data not shown). Purified
TTR presented in Fig. 2 (A) (lane 3) was slightly shifted compared with native TTR, either because it was partially 'denatured' or devoid of retinol-binding protein after purification.

The binding of $\left[{ }^{125} \mathrm{I}_{\mathrm{T}}\right.$ to TTR in the presence of saturating concentrations of soya isoflavones is presented in Fig. 3. The sigmoidal dose-response curves describe the relationships between the isoflavones' concentration and $\left[{ }^{125} \mathrm{I}\right] \mathrm{T}_{4}$ bound to human purified TTR. Genistein was the strongest competitor, showing practically the same displacement as the unlabelled $\mathrm{L}-\mathrm{T}_{4}$ used as a control in each experiment $\left(\mathrm{IC}_{50}=0.07\right.$ and $0.08 \mu \mathrm{M}$, respectively). Glycitein inhibited $\left[{ }^{125} \mathrm{I}\right] \mathrm{T}_{4}$ binding to TTR with about four times less potency $\left(\mathrm{IC}_{50}=0.2 \mu \mathrm{M}\right)$ and daidzein was the weakest competitor for binding to TTR $\left(\mathrm{IC}_{50}=1.8 \mu \mathrm{M}\right)$. Scatchard analysis of the representative binding data yielded the following dissociation constants: $\mathrm{T}_{4}(65$ (SD 19) nM); genistein (59 (SD 13) nM); glycitein (71 (SD 22) nM); daidzein (131 (SD 109) nM).

\section{Discussion}

The results presented in the present in vitro study clearly demonstrate the inhibitory effect of soya isoflavones on the binding of $\mathrm{T}_{4}$ to the serum and CSF thyroid hormone transport
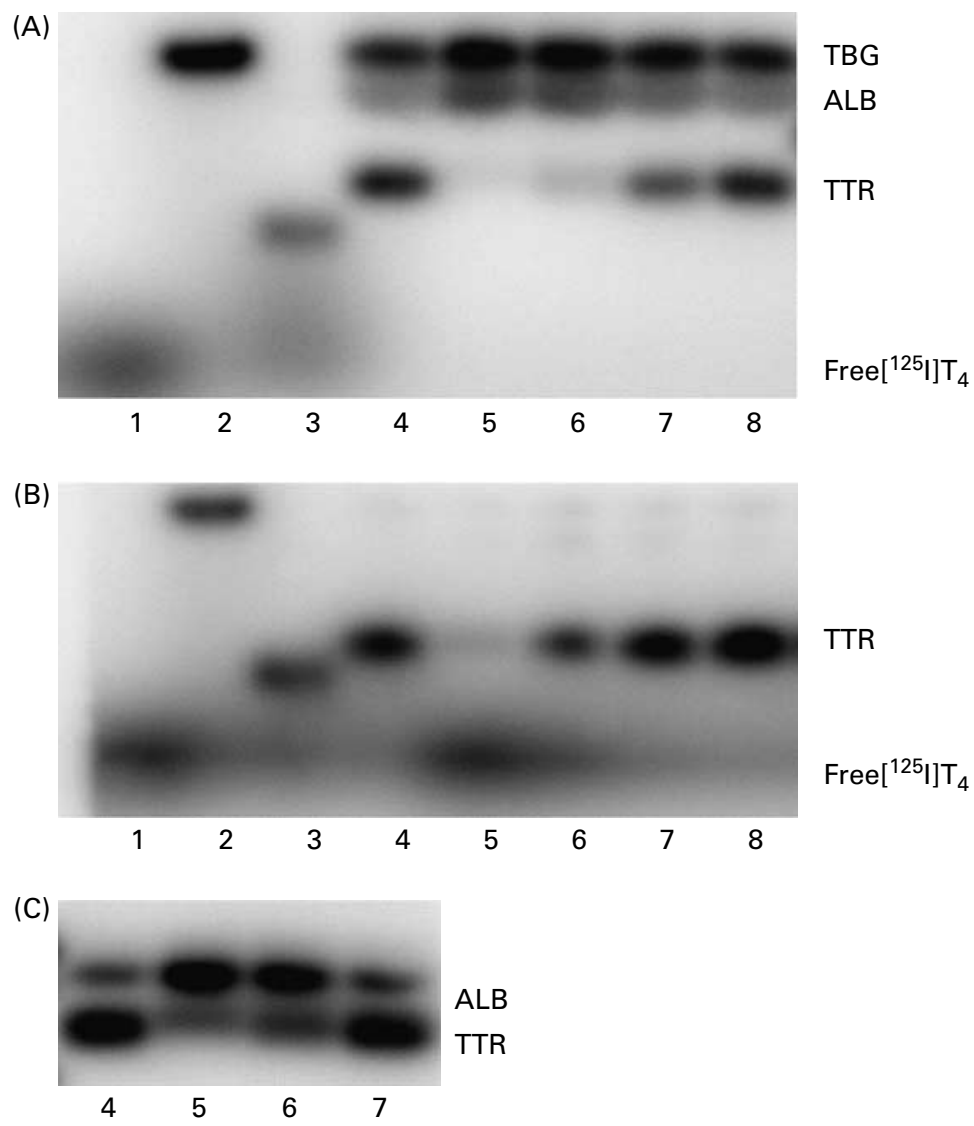

Fig. 2. Representative autoradiographs of $\left[{ }^{125} \mathrm{I}\right]$ thyroxine $\left(\left[{ }^{125} \mathrm{I}\right] \mathrm{T}_{4}\right)$ bound to serum and cerebrospinal fluid (CSF) thyroid hormone-binding proteins. Effect of the isoflavone genistein added in vitro on binding of $\left[{ }^{125} \mathrm{I}\right] \mathrm{T}_{4}$ to binding proteins in $(A)$ human serum, (B) human CSF and (C) rat serum. In (A) the lanes are: lane 1 , free $\left[{ }^{125}{ }^{1} \mathrm{~T}_{4}\right.$; lane 2, purified human thyroxine-binding globulin (TBG); lane 3, purified human transthyretin (TTR); lane 4, control human serum; lane 5, human serum $+100 \mu \mathrm{M}$-genistein; lane 6 , human serum $+10 \mu \mathrm{M}$-genistein; lane 7 , human serum $+1 \mu \mathrm{M}$-genistein; lane 8 , human serum $+0 \cdot 1 \mu \mathrm{M}$-genistein. In (B) the lanes are: lane 1, free $\left[{ }^{125} I\right] T_{4}$; lane 2, purified human TBG; lane 3, purified human TTR; lane 4, control human CSF; lane 5, CSF +100 $\mu$ M-genistein; lane 6, CSF $+10 \mu \mathrm{M}$-genistein; lane $7, \mathrm{CSF}+1 \mu \mathrm{M}$-genistein; lane $8, \mathrm{CSF}+0.1 \mu \mathrm{M}$-genistein. In $(\mathrm{C})$ the lanes are: lane 4 , control rat serum; lane 5 , rat serum $+100 \mu \mathrm{M}$-genistein; lane 6 , rat serum $+10 \mu \mathrm{M}$-genistein; lane 7 , rat serum $+1 \mu \mathrm{M}$-genistein. ALB, albumin. 


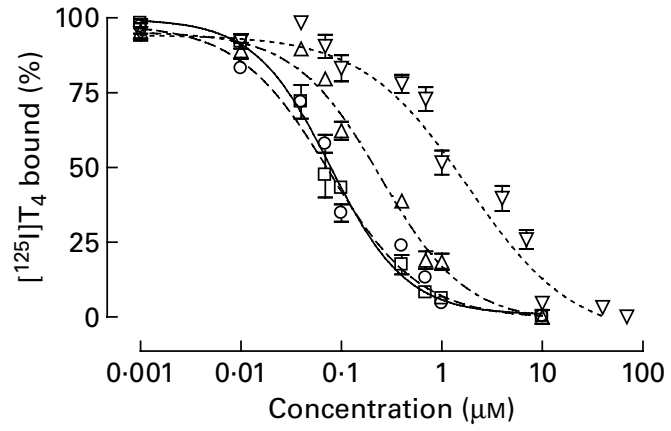

Fig. 3. Dose-response displacement of $\left[{ }^{125} \mid\right]$ thyroxine $\left(\left[{ }^{125} I\right] T_{4} ; \square\right)$ from transthyretin (TTR) by soya isoflavones genistein $(O)$, glycitein $(\Delta)$ and daidzein $(\nabla)$. Data points are mean values of at least three measurements in duplicate, with standard deviations represented by vertical bars. $\left[{ }^{125} \mid\right] T_{4}-$ TTR binding data were normalised for each experiment to span the range from 0 to $100 \%$. Values for $50 \%$ inhibitory concentration $(\mu \mathrm{M})$ were: $\mathrm{T}_{4}, 0.08$; genistein, 0.07 ; glycitein, 0.2 ; daidzein 1.8 .

protein, TTR. As no competition was observed for the binding of $\left[{ }^{125} \mathrm{I}_{\mathrm{T}}\right.$ to albumin and TBG (data not shown), the addition of soya isoflavones to rat and human serum resulted in the displacement of $\left[{ }^{125} \mathrm{I}\right] \mathrm{T}_{4}$ from TTR to these transport proteins. Displacement also occurred in human CSF, but because of the absence of other specific binding proteins for $\mathrm{T}_{4}$, the free $\left[{ }^{125} \mathrm{I}\right] \mathrm{T}_{4}$ fraction was evidently increased. Genistein was the strongest competitor, showing binding affinity comparable with that of unlabelled $\mathrm{T}_{4}$. Glycitein and daidzein exhibited lower competition potency. Selective binding of genistein and daidzein to TTR in plasma determined by an antibody capture-HPLC method, as recently published by Green et al. (2005), is in agreement with the present data.

The results presented in the present study are highly relevant both biologically and medically because the obtained $\mathrm{IC}_{50}$ concentrations are in the range of published soya isoflavone plasma concentrations. Doerge \& Sheehan (2002) reported that adults eating typical Asian diets have blood concentrations of $0 \cdot 1-1 \cdot 2 \mu \mathrm{mol}$ total soya isoflavones/l. Three adult volunteers had concentrations of $0.5-0.9 \mu \mathrm{mol} / \mathrm{l}$ after eating soya nutritional supplements and even $2-7 \mu \mathrm{mol} / \mathrm{l}$ concentrations of soya isoflavones were measured in the serum of seven infants eating soya infant formula. Manach et al. (2005) reviewed ninety-seven polyphenol bioavailability studies and showed similar results; for example, concentrations of 1.74 and $1.33 \mu \mathrm{mol}$ genistein/l were measured in plasma $6 \mathrm{~h}$ after intake of soya milk and tofu, respectively. As these values are far above $\mathrm{IC}_{50}$ values obtained in vitro for genistein $(0.07 \mu \mathrm{mol} / \mathrm{l})$ and even glycitein $(0.2 \mu \mathrm{mol} / \mathrm{l})$, displacement of $\mathrm{T}_{4}$ from TTR could be equally possible in vivo. Altered binding of $\mathrm{T}_{4}$ to TTR, associated with altered free thyroid hormone levels, might be possible and might exert physiological effects. Watanabe et al. (2000) reported altered $\mathrm{T}_{4}$ and triiodothyronine values in young premenopausal women, after administration of physiological doses of isoflavones. Similar doses of soya isoflavones caused only modest hormonal effects in postmenopausal women (Duncan et al. 1999). Selective binding of (iso)flavonoids to TTR might also indicate a role of TTR in distribution and targeting of soya isoflavones to steroid-regulated tissues, an effect independent of $\mathrm{T}_{4}$ competition. As reported by Cassidy et al. (1994) and Watanabe et al. (2000), physiological doses of isoflavones can cause changes in sex hormone production and perturb menstruation. The recently published data (Jefferson et al. 2005) indicate a potential deleterious role of isoflavones during pregnancy, which is of particular concern. The authors reported that neonatal exposure to genistein at environmentally relevant doses caused abnormal oestrous cycles, altered ovarian function, early reproductive senescence, and subfertility in mice. Whether TTR itself or altered thyroid hormone economy as suggested by the present observations contribute to alterations of the reproductive axis reported by Jefferson et al. (2005) remains to be studied.

Competitive in vitro binding with TTR in CSF revealed a clear increase in free $T_{4}$ concentration because there is no other alternative specific thyroid hormone carrier able to bind displaced $\mathrm{T}_{4}$. TBG is not present in CSF (Davidsson et al. 2001; Matsumoto et al. 2003) and the amount of albumin which has the lowest affinity to bind $\mathrm{T}_{4}$ (Tabachnick \& Giorgio, 1964) is too low compared with TTR to bind displaced $\left[{ }^{125} \mathrm{I}_{\mathrm{T}}\right.$. Chanoine et al. (1992) also reported the transient increase in serum and CSF free $\mathrm{T}_{4}$ concentration after administering low and high doses of synthetic flavonoid EMD21388, respectively. However, the occupation of the sole hormone distributor protein and evident disturbance in binding properties postulate an effect on brain metabolism, if it is known that thyroid hormones are intimately involved in the regulation of the central nervous system. Experimental studies show that the central nervous system has strict requirements for thyroid hormones; in the brain, the concentrations of both $\mathrm{T}_{4}$ and the more active metabolite triiodothyronine tend to be kept within a narrow range even in the presence of extreme fluctuations of circulating $\mathrm{T}_{4}$ level (Dratman et al. 1983). This fact additionally underlines the importance of TTR binding in CSF considering that TTR binds both $\mathrm{T}_{4}$ and triiodothyronine (although having different affinities) (Cody, 2002), which are present in equimolar concentration in the brain in contrast to the serum. However, further in vivo studies are required to clarify the physiological and molecular implications of disturbed $\mathrm{T}_{4}$ binding, particularly on the central nervous system.

The negative influence of soya isoflavones on thyroid hormone synthesis by means of blocking thyroid peroxidase has been well described in vitro and in vivo. Numerous studies on rats and human subjects raise concerns on anti-thyroid effects, including goitre formation, especially in infants consuming soya formula (van Wyk et al. 1959; Hydovitz, 1960; Shepard et al. 1960; Ripp, 1961; Pinchera et al. 1965; Kay et al. 1988; Labib et al. 1989; Ishizuki et al. 1991; Chorazy et al. 1995; Jabbar et al. 1997; Ikeda et al. 2000). There are also opposite reports (Klein, 1998; Merritt \& Jenks, 2004) indicating that dietary isoflavones in soya infant formulas do not adversely affect human health. Besides the inhibitory effects of flavonoids on thyroid peroxidase, iodine deficiency is a very important risk factor for thyroid dysfunction and goitre development in both man and rats. An adequate iodine supply is absolutely advantageous for preventing the goitrogenic effects of soya isoflavones, especially in the relatively high-risk group of patients with congenital hypothyroidism solely dependent on exogenous thyroid hormone supply, or in patients with transient hypothyroidism after thyroidectomy. The present data contribute to unveiling the mechanism of action of soya isoflavones in goitrogenesis and disturbance 
of the thyroid hormone homeostasis, while emphasising the role of binding and distributor proteins, particularly TTR.

TTR is the main thyroid hormone transport protein in rodents, but, in man, despite the 20-fold higher concentration in serum relative to that of TBG, it plays a lesser role in iodothyronine transport (Woeber \& Ingbar, 1968). Only a minor fraction of $\mathrm{T}_{4}$ is bound to serum albumin in both man and rats, despite the very high binding capacity (Köhrle et al. 1989). In vitro and in vivo competitive-binding studies have revealed up to now that flavonoids interfere with $\mathrm{T}_{4}$ binding, not with all thyroid hormone distribution proteins, but preferentially with TTR (Köhrle, 2000). TTR is a highly conserved tetrameric protein with two binding domains and three pairs of halogen-binding pockets in each of them (Cody, 2002). At physiological conditions, only one $\mathrm{T}_{4}$ binding domain is occupied, since the negative cooperativity in binding to the second domain decreases the binding affinity of a second hormone molecule (Ferguson et al. 1975). Structural data for the human TTR $-T_{4}$ complex has revealed that $\mathrm{T}_{4}$ binds in a 'forward' mode with its phenolic $\mathrm{OH}$ group buried deep within the binding channel, while the synthetic flavone EMD21388 binds to human TTR in a manner different from $\mathrm{T}_{4}$ (Cody, 2002). After $12 \mathrm{~h}$ incubation with EMD21388, binding occurred only in one domain in a 'forward' mode, while $24 \mathrm{~h}$ incubation data showed forward binding in both domains with the bromoflavone bound deeper in the channel than $\mathrm{T}_{4}$. After $48 \mathrm{~h}$ incubation EMD21388 binds in both a 'forward' mode and a 'reverse' mode. Ciszak et al. (1992) reported the similar binding manner for a bromoaurone analogue. The fact that soya isoflavones tested in the present study have a similar structure to synthetic bromoflavone means that a similar binding manner could be expected. Therefore, soya isoflavones could also exhibit alternative binding orientations, which may explain such strong binding affinities for TTR (Auf' mkolk et al. 1986). Structure-activity correlation in the present study revealed the soya isoflavone genistein as the strongest binding competitor, indicating the same binding potency as $\mathrm{L}_{-} \mathrm{T}_{4}$. Obviously, the 5-OH group is important for binding, most probably by occupying one of the three halogen-binding pockets, while the 7-OH group in the meta-position occupies the other. In addition, the ability of the 5-OH group of genistein to form an intramolecular hydrogen bond with the 4-keto group leading to a pseudo aromatic ring (Chen et al. 1995 ) could also participate in increased binding to TTR compared with other soya isoflavones. The reason for the ten-fold increase in binding potency of glycitein compared with daidzein should be searched for in the 6-methoxy group which is absent in daidzein. According to Cody (2002), the presence of the 3methyl of EMD21388 appears crucial for effective binding and stabilisation of the TTR tetramer. The important van der Waal's interactions may also be formed between the 6-methoxy group of daidzein and adequate amino acids in the binding pocket. However, the further crystallographic analyses of TTR-ligand co-crystal complexes are required to clarify these structure-activity relationships.

Naturally occurring chalcones, including phloretin, aurones and flavonoids, exhibit a clear concentration-dependent displacement of $\mathrm{T}_{4}$ from TTR binding in vitro with $\mathrm{IC}_{50}$ values in the range of $0 \cdot 1-50 \mu \mathrm{M}$ (Köhrle, 2000). The present data contribute to competition-binding studies made thus far, therefore revealing the isoflavone genistein as the strongest naturally occurring $\mathrm{T}_{4}$ competitor. Further in vivo studies will clarify the expected disturbance in the feedback regulation of hormonal networks, including the pituitary-thyroid-periphery axis and will shed more light on the role of TTR in this feedback circuit.

\section{Acknowledgements}

We thank Ms Manuela Topp and Ms Anita Kinne for perfect technical assistance and Dr Lutz Schomburg for useful discussion. The present study was supported by the German Research Council (Deutsche Forschungsgemeinschaft), no. Ko 922/12-1.

\section{References}

Akiyama T, Ishida J, Nakagawa S, Ogawara H, Watanabe S, Itoh N, Shibuya M \& Fukami Y (1987) Genistein, a specific inhibitor of tyrosine-specific protein kinases. J Biol Chem 262, 5592-5595.

Anderson JW, Smith BM \& Washnock CS (1999) Cardiovascular and renal benefits of dry bean and soybean intake. Am J Clin Nutr $\mathbf{7 0}$, 464-474.

Auf'mkolk M, Koehrle J, Hesch RD \& Cody V (1986) Inhibition of rat liver iodothyronine deiodinase. Interaction of aurones with the iodothyronine ligand-binding site. J Biol Chem 261, 11623-11630.

Block JR, Mand RH, Howard HW, Bauer CD \& Anderson DW (1961) The curative action of iodine on soybean goiter and the changes in the distribution of iodoamino acids in the serum and in the thyroid gland digests. Arch Biochem Biophys 93, 15-24.

Cassidy A, Bingham S \& Setchell KD (1994) Biological effects of a diet of soy protein rich in isoflavones on the menstrual cycle of premenopausal women. Am J Clin Nutr 60, 333-340.

Chang HC \& Doerge DR (2000) Dietary genistein inactivates rat thyroid peroxidase in vivo without an apparent hypothyroid effect. Toxicol Appl Pharmacol 168, 244-252.

Chanoine JP, Alex S, Fang SL, Stone S, Leonard JL, Kohrle J \& Braverman LE (1992) Role of transthyretin in the transport of thyroxine from the blood to the choroid plexus, the cerebrospinal fluid, and the brain. Endocrinology 130, 933-938.

Chen S, Deng PS-K, Swiderek K, Li M \& Chan SI (1995) Interaction of flavones and their bromoacetyl derivatives with $\mathrm{NAD}(\mathrm{P}) \mathrm{H}$ : quinone acceptor oxidoreductase. Mol Pharmacol 47, 419-424.

Chorazy PA, Himelhoch S, Hopwood NJ, Greger NG \& Postellon DC (1995) Persistent hypothyroidism in an infant receiving a soy formula: case report and review of the literature. Pediatrics 96 $148-150$.

Ciszak E, Cody V \& Luft JR (1992) Crystal structure determination at 2 3-A resolution of human transthyretin- $3^{\prime}, 5^{\prime}$-dibromo- $2^{\prime}, 4,4^{\prime}, 6$-tetrahydroxyaurone complex. Proc Natl Acad Sci $U$ S A 89, $6644-6648$.

Cody V (2002) Mechanisms of molecular recognition: crystal structure analysis of human and rat transthyretin inhibitor complexes. Clin Chem Lab Med 40, 1237-1243.

Cross HS, Kallay E, Lechner D, Gerdenitsch W, Adlercreutz H \& Armbrecht HJ (2004) Phytoestrogens and vitamin D metabolism: a new concept for the prevention and therapy of colorectal, prostate, and mammary carcinomas. J Nutr 134, 1207-1212.

Davidsson P, Paulson L, Hesse C, Blennow K \& Nilsson CL (2001) Proteome studies of human cerebrospinal fluid and brain tissue using a preparative two-dimensional electrophoresis approach prior to mass spectrometry. Proteomics 1, 444-452.

Divi RL, Chang HC \& Doerge DR (1997) Anti-thyroid isoflavones from soybean:isolation, characterization, and mechanisms of action. Biochem Pharmacol 54, 1087-1096.

Dixon RA \& Ferreira D (2002) Genistein. Phytochemistry 60, $205-211$. 
Doerge DR \& Sheehan DM (2002) Goitrogenic and estrogenic activity of soy isoflavones. Environ Health Perspect 110, 349-353.

Dratman MB, Crutchfield FL, Gordon JT \& Jennings AS (1983) Iodothyronine homeostasis in rat brain during hypo- and hyperthyroidism. Am J Physiol 245, 185-193.

Duncan AM, Underhill KE, Xu X, Lavalleur J, Phipps WR \& Kurzer MS (1999) Modest hormonal effects of soy isoflavones in postmenopausal women. J Clin Endocrinol Metab 84, 3479-3484.

Duncan RE, El-Sohemy A \& Archer MC (2005) Regulation of HMGCoA reductase in MCF-7 cells by genistein, EPA, and DHA, alone and in combination with mevastatin. Cancer Lett 224, 221-228.

Ebmeier CC \& Anderson RJ (2004) Human thyroid phenol sulfotransferase enzymes 1A1 and 1A3: activities in normal and diseased thyroid glands, and inhibition by thyroid hormones and phytoestrogens. J Clin Endocrinol Metab 89, 5597-5605.

Ferguson RN, Edelhoch H, Saroff HA, Robbins J \& Cahnmann HJ (1975) Negative cooperativity in the binding of thyroxine to human serum prealbumin. Preparation of tritium-labelled 8-anilino-1-naphthalenesulfonic acid. Biochemistry 14, 282-289.

Green NS, Foss TR \& Kelly JW (2005) Genistein, a natural product from soy, is a potent inhibitor of transthyretin amyloidosis. Proc Natl Acad Sci U S A 102, 14545-14550.

Hydovitz JD (1960) Occurrence of goiter in an infant on a soy diet. $N$ Engl J Med 262, 351-353.

Ikeda T, Nishikawa A, Imazawa T, Kimura S \& Hirose M (2000) Dramatic synergism between excess soybean intake and iodine deficiency on the development of rat thyroid hyperplasia. Carcinogenesis 21, 707-713.

Ishizuki Y, Hirooka Y, Murata Y \& Togashi K (1991) The effects on the thyroid gland of soybeans administered experimentally in healthy subjects. Nippon Naibunpi Gakkai Zasshi 67, 622-629.

Jabbar MA, Larrea J \& Shaw RA (1997) Abnormal thyroid function tests in infants with congenital hypothyroidism: the influence of soy-based formula. J Am Coll Nutr 16, 280-282.

Jefferson WN, Padilla-Banks E \& Newbold RR (2005) Adverse effects on female development and reproduction in CD-1 mice following neonatal exposure to the phytoestrogen genistein at environmentally relevant doses. Biol Reprod 73, 798-806.

Jin Z \& MacDonald RS (2002) Soy isoflavones increase latency of spontaneous mammary tumors in mice. J Nutr 132, 3186-3190.

Kay T, Kimura M, Nishing K \& Itokawa Y (1988) Soyabean, goitre, and prevention. J Trop Pediatr 34, 110-113.

Klein KO (1998) Isoflavones, soy-based infant formulas, and relevance to endocrine function. Nutr Rev 56, 193-204.

Köhrle J (2000) Flavonoids as a risk factor for goiter and hypothyroidism. In The Thyroid and Environment. Proceedings of the Merck European Thyroid Symposium, pp. 41-63 [F Péter, WM Wiersinga and U Hostalek, editors]. Stuttgart and New York: Schattauer.

Köhrle J, Fang SL, Yang Y, Irmscher K, Hesch RD, Pino S, Alex S \& Braverman LE (1989) Rapid effects of the flavonoid EMD 21388 on serum thyroid hormone binding and thyrotropin regulation in the rat. Endocrinology 125, 532-537.

Konijn AM, Edelstein S \& Guggenheim K (1972) Separation of a thyroid-active fraction from unheated soy bean flour. J Sci Food Agric 23, 549-555.
Kuiper GG, Lemmen JG, Carlsson B, Corton JC, Safe SH, van der Saag PT, van der Burg B \& Gustafsson JA (1998) Interaction of estrogenic chemicals and phytoestrogens with estrogen receptor beta. Endocrinology 139, 4252-4263.

Labib M, Gama R, Wright J, Marks V \& Robins D (1989) Dietary maladvice as a cause of hypothyroidism and short stature. $B M J$ 298, 232-233.

Lissin LW \& Cooke JP (2000) Phytoestrogens and cardiovascular health. J Am Coll Cardiol 35, 1403-1410.

Manach C, Williamson G, Morand C, Scalbert A \& Remesy C (2005) Bioavailability and bioefficacy of polyphenols in humans. I Review of 97 bioavailability studies. Am J Clin Nutr 81, 230-242.

Matsumoto N, Kitayama H, Kitada M, Kimura K, Noda M \& Ide C (2003) Isolation of a set of genes expressed in the choroid plexus of the mouse using suppression subtractive hybridization. Neuroscience 117, 405-415.

Merritt RJ \& Jenks BH (2004) Safety of soy-based infant formulas containing isoflavones: the clinical evidence. $J$ Nutr 134, $1220-1224$.

Messina MJ (1999) Legumes and soybeans: overview of their nutritional profiles and health effects. Am J Clin Nutr 70, 439-450.

Newbold RR, Banks EP, Bullock B \& Jefferson WN (2001) Uterine adenocarcinoma in mice treated neonatally with genistein. Cancer Res 61, 4325-4328.

Nordsiek FW (1962) Effects of added casein on goitrogenic action of different dietary levels of soybeans. Proc Soc Exp Biol Med 110, 417-420.

Pinchera A, MacGillivray MH, Crawford JD \& Freeman AG (1965) Thyroid refractoriness in an athyreotic cretin fed soybean formula. $N$ Engl J Med 273, 83-87.

Ripp JA (1961) Soybean-induced goiter. Am J Dis Child 102, 106-109.

Shepard TH, Pyne GE, Kirschvink JF \& McLean M (1960) Soybean goiter. N Engl J Med 262, 1099-1103.

Somack R, Andrea TA \& Jorgensen EC (1982) Thyroid hormone binding to human serum prealbumin and rat liver nuclear receptor: kinetics, contribution of the hormone phenolic hydroxyl group, and accommodation of hormone side-chain bulk. Biochemistry 21, $163-170$.

Tabachnick M \& Giorgio NA Jr (1964) Thyroxine-protein interactions II. The binding of thyroxine and its analogues to human serum albumin. Arch Biochem Biophys 105, 563-569.

Tham DM, Gardner CD \& Haskell WL (1998) Clinical review 97: Potential health benefits of dietary phytoestrogens: a review of the clinical, epidemiological, and mechanistic evidence. J Clin Endocrinol Metab 83, 2223-2235.

van Wyk JJ, Arnold MB, Wynn J \& Pepper F (1959) The effects of a soybean product on thyroid function in humans. Pediatrics 24, 752-760.

Watanabe S, Terashima K, Sato Y, Arai S \& Eboshida A (2000) Effects of isoflavone supplement on healthy women. Biofactors 12, 233-241.

Woeber KA \& Ingbar SH (1968) The contribution of thyroxine-binding prealbumin to the binding of thyroxine in human serum, as assessed by immunoadsorption. J Clin Invest 47, 1710-1721.

Young RA, Braverman LE \& Rajatanavin R (1982) Low protein-high carbohydrate diet induces alterations in the serum thyronine-binding proteins in the rat. Endocrinology 110, 1607-1612. 